\title{
DPP-4 inhibitors in the management of type 2 diabetes: A critical review of head-to-head trials
}

\author{
A.J. Scheen \\ Division of Diabetes, Nutrition and Metabolic Disorders, and Division of Clinical Pharmacology, Department of Medicine, CHU Sart \\ Tilman (B35), University of Liège, 4000 Liège, Belgium
}

\begin{abstract}
Dipeptidyl peptidase-4 (DPP-4) inhibitors offer new options for the management of type 2 diabetes. Direct comparisons with active glucose-lowering comparators in drug-naive patients have demonstrated that DPP-4 inhibitors exert slightly less pronounced $\mathrm{HbA}_{1 \mathrm{c}}$ reduction than metformin (with the advantage of better gastrointestinal tolerability) and similar glucose-lowering effects as with a thiazolidinedione (TZD; with the advantage of no weight gain). In metformin-treated patients, gliptins were associated with similar $\mathrm{HbA}_{1 \mathrm{c}}$ reductions compared with a sulphonylurea $(\mathrm{SU}$; with the advantage of no weight gain, considerably fewer hypoglycaemic episodes and no need for titration) and a TZD (with the advantage of no weight gain and better overall tolerability). DPP-4 inhibitors also exert clinically relevant glucose-lowering effects compared with a placebo in patients treated with SU or TZD (of potential interest when metformin is either not tolerated or contraindicated), and as oral triple therapy with a good tolerability profile when added to a metformin-SU or pioglitazone-SU combination. Several clinical trials also showed a consistent reduction in $\mathrm{HbA}_{1 \mathrm{c}}$ when DPP-4 inhibitors were added to basal insulin therapy, with no increased risk of hypoglycaemia. Because of the complex pathophysiology of type 2 diabetes and the complementary actions of glucose-lowering agents, initial combination of a DPP-4 inhibitor with either metformin or a glitazone may be applied in drug-naive patients, resulting in greater efficacy and similar safety compared with either drug as monotherapy. However, DPP-4 inhibitors were less effective than GLP-1 receptor agonists for reducing $\mathrm{HbA}_{1 \mathrm{c}}$ and body weight, but offer the advantage of being easier to use (oral instead of injected administration) and lower in cost. Only one head-tohead trial demonstrated the non-inferiority of saxagliptin vs sitagliptin. Clearly, more trials of direct comparisons between different incretin-based therapies are needed. Because of their pharmacokinetic characteristics, pharmacodynamic properties (glucose-dependent glucose-lowering effect) and good overall tolerability profile, DPP-4 inhibitors may have a key role to play in patients with renal impairment and in the elderly. The role of DPP-4 inhibitors in the therapeutic armamentarium of type 2 diabetes is rapidly evolving as their potential strengths and weaknesses become better defined mainly through controlled clinical trials.
\end{abstract}

Keywords: Clinical trial-DPP-4 inhibitor; Alogliptin; Linagliptin; Saxagliptin; Sitagliptin; Vildagliptin; Type 2 diabetes mellitus; Review

\section{Résumé}

Les inhibiteurs de la DPP-4 dans le traitement du diabète de type 2 : revue critique des essais cliniques contrôlés.

Les inhibiteurs de la dipeptidylpeptidase-4 (DPP-4) offrent de nouvelles options pour le traitement du diabète de type 2. Des comparaisons directes avec d'autres médicaments antidiabétiques chez des patients naïfs de tout traitement ont démontré que les inhibiteurs de la DPP-4 étaient un peu moins puissants pour diminuer le taux $\mathrm{d}^{\prime} \mathrm{HbA}_{\mathrm{lc}}$ que la metformine (avec l'avantage d'une meilleure tolérance digestive) et aussi puissants que les thiazolidinediones (avec l'avantage d'une neutralité pondérale). Chez les patients déjà traités par metformine, les gliptines entraînent une baisse des taux $\mathrm{d}^{\prime} \mathrm{HbA}_{1 \mathrm{c}}$ similaire à celle observée avec les sulfamides (mais sans prise de poids, sans hypoglycémie et sans nécessité de titration) ou avec les thiazolidinediones (avec l'avantage de l'absence de prise de poids et d'un meilleur profil de tolérance). Les inhibiteurs de la DPP-4 améliorent aussi le contrôle glycémique par rapport à un placebo chez les patients traités avec un sulfamide ou une thiazolidinedione (ce qui peut être intéressant chez les patients pour lesquels la metformine est non tolérée ou contre-indiquée) ou encore en triple thérapie orale en étant ajoutés à une combinaison metformine-sulfamide ou pioglitazonesulfamide, avec toujours un bon profil de tolérance. Plusieurs essais cliniques ont montré une diminution consistante des taux d'HbA $\mathrm{H}_{1 \mathrm{c}}$ lorsqu'un inhibiteur de la DPP-4 était ajouté à une insulinothérapie basale, sans accroître le risque d'hypoglycémie. En raison de la physiopathologie complexe du diabète de type 2 et de la complémentarité d'action des médicaments hypoglycémiants, une combinaison initiale d' un inhibiteur de la DPP-4 avec soit la metformine, soit une glitazone peut être proposée chez les patients insuffisamment contrôlés par régime et exercice, avec une meilleure efficacité et une aussi bonne tolérance qu'une monothérapie 
pharmacologique initiale. Les inhibiteurs de la DPP-4 sont moins efficaces que les agonistes des récepteurs du glucagon-like peptide-1 en ce qui concerne la diminution des taux $\mathrm{d}^{\prime} \mathrm{HbA}_{1 \mathrm{c}}$ et du poids, mais offrent le bénéfice d'un usage plus facile (prise orale au lieu d'une injection) et d'un coût moins élevé. Un seul essai clinique comparatif direct a été publié à ce jour entre deux inhibiteurs de la DPP-4, démontrant une non infériorité de la saxagliptine par rapport à la sitagliptine. De toute évidence, davantage d'essais cliniques devraient offrir une comparaison directe entre les différents traitements fondés sur l'effet incrétine. En raison de leurs caractéristiques pharmacocinétiques, de leurs propriétés pharmacodynamiques (effet hypoglycémiant glucose-dépendant) et de leur bon profil de tolérance, les gliptines devraient occuper une place de choix chez les patients avec une insuffisance rénale ou chez les sujets âgés. Le rôle des inhibiteurs de la DPP-4 dans l'arsenal thérapeutique du diabète de type 2 évolue rapidement au fur et à mesure que leurs avantages et inconvénients apparaissent mieux définis, essentiellement grâce aux essais cliniques contrôlés.

Mots clés : Diabète de type 2 ; Essai clinique ; Inhibiteur de la DPP-4 ; Alogliptine ; Linagliptine ; Saxagliptine ; Sitagliptine ; Vildagliptine ; Revue générale

\section{Introduction}

Dipeptidyl peptidase-4 (DPP-4) inhibitors are a novel pharmacological class of glucose-lowering agents that open up new perspectives for the management of type 2 diabetes mellitus (T2DM). The mechanism of action of DPP-4 inhibitors is distinct from any existing class of oral glucose-lowering agents [1]. Although they are not more potent in lowering blood glucose concentrations and reducing glycated haemoglobin $\left(\mathrm{HbA}_{1 \mathrm{c}}\right)$ levels [2], DPP-4 inhibitors nevertheless offer several clinically relevant advantages [3-5]. Among the most important benefits are a negligible risk of hypoglycaemia that is considerably lower than that observed with sulphonylurea (SU), and a weight-neutral profile in contrast to the weight gain generally observed with SU and thiazolidinedione (TZD). DPP-4 inhibitors have been evaluated as monotherapy and in various combinations with other glucose-lowering agents, and compared with either a placebo or an agent of another glucose-lowering pharmacological class as an active comparator [6].

The present review is an updated evaluation of five DPP-4 inhibitors (sitagliptin, vildagliptin, saxagliptin, alogliptin and linagliptin) in randomized clinical trials in the literature so far, and focuses particularly on the following topics:

- direct comparisons with active glucose-lowering comparators in drug-naive or metformin-treated patients;

- comparisons with placebo or active comparators in more unusual indications as an add-on to SU or TZD, as oral triple therapy or as an add-on to insulin;

- use as the initial combination with metformin or TZD in drug-naive patients;

- comparisons with glucagon-like peptide-1 (GLP-1) receptor agonists or other gliptins in head-to-head trials;

- use of DPP-4 inhibitors in special populations, especially patients with renal impairment and the elderly.

\section{Methods}

To identify the relevant studies, an extensive literature search of Medline was performed from January 2005 to August 2011, using the term "DPP-4 inhibitors", and the generic names "sitagliptin", "vildagliptin",

"saxagliptin", "alogliptin" and "linagliptin". No language restrictions were imposed. Reference lists of original studies, narrative reviews and previous systematic reviews were also carefully examined. Only clinical trials that randomized at least 100 T2DM patients and lasted at least 12 weeks were considered. Most of the studies ran for 24-26 weeks, with a maximum follow-up duration of 104 weeks in a few cases.

\section{Results}

\subsection{Gliptins as monotherapy or as add-ons to metformin}

Numerous placebo-controlled trials have demonstrated both the efficacy and safety of DPP-4 inhibitors in patients with T2DM treated with diet and exercise (drug-naive patients), and in patients treated with metformin monotherapy, the first-line drug choice for T2DM. All of these trials showed that DPP-4 inhibitors reduced $\mathrm{HbA}_{\mathrm{lc}}$, fasting plasma glucose and postprandial glucose levels without inducing hypoglycaemia, with near weight neutrality and a tolerability profile that did not differ from that of placebo. These trials have already been summarized in various reviews [7] and meta-analyses [2,8]. Clinically relevant reductions in $\mathrm{Hb}_{\mathrm{lc}}$ were obtained with a gliptin across a wide range of T2DM patient subgroups examined by either specific baseline 
demographic characteristics or $\beta$-cell function indices such as the homoeostatic model assessment (HOMA)- $\beta$ [9]. Our present report has specifically compared DPP-4 inhibitors with active glucose-lowering comparators (instead of a placebo) to better delineate the potential advantages (and disadvantages) of DPP-4 inhibitors in clinical use.

\subsubsection{Gliptins as monotherapy}

As metformin is considered the first-line drug therapy for the management of T2DM [10,11], it is of interest to compare the efficacy (and safety) of aDPP-4 inhibitor with that of metformin in drug-naive T2DM patients insufficiently controlled with diet and exercise [12-21]. Overall, metformin (1000-2000 mg/day) demonstrated slightly (but significantly) greater reductions in both $\mathrm{HbA}_{1 \mathrm{c}}$ and body weight (Table 1, Fig. 1). However, the DPP-4 inhibitor showed superior gastrointestinal tolerability compared with metformin. Nevertheless, these comparative results do not support the initial use of a DPP-4 inhibitor instead of the reference drug metformin except in patients for whom metformin is either not well tolerated (gastrointestinal adverse events) or is contraindicated (for instance, renal insufficiency).

Only three head-to-head trials have compared a DPP-4 inhibitor with a TZD (two with pioglitazone $30 \mathrm{mg}$ and one with rosiglitazone $8 \mathrm{mg}$ ) [22-24]. Overall, the reduction in $\mathrm{HbA}_{1 \mathrm{c}}$ was similar with the two pharmacological approaches, with a low incidence of hypoglycaemic events. However, the TZDs were associated with significant weight gain in contrast to the weight neutrality of gliptins (Table 1, Fig. 1).

Two studies compared a DPP-4 inhibitor with an alpha-glucosidase inhibitor as monotherapy in patients with T2DM. One trial compared vildagliptin $50 \mathrm{mg}$ with acarbose (titrated up to $3 \times 100 \mathrm{mg}$ ) and reported similar $\mathrm{HbA}_{1 \mathrm{c}}$ reductions with the two compounds [25], while the other trial demonstrated that linagliptin (5 or 10mg once a day) had greater efficacy than voglibose $(3 \times 0.2 \mathrm{mg}$ /day) for improving glycaemic control [26]. In both these studies, drug-related gastrointestinal disorders were more common with the alpha-glucosidase inhibitor than with the DPP-4 inhibitor (Table 1).

\subsubsection{Gliptins combined with metformin}

As metformin is considered the first-line drug in T2DM, most combination trials have tested the efficacy and safety of adding a DPP-4 inhibitor to baseline metformin monotherapy, and found that adding any gliptin was superior to a placebo, with a mean reduction in $\mathrm{HbA}_{1 \mathrm{c}}$ of $0.6-0.8 \%$ [7]. However, in the present review, only head-to-head trials vs active comparators are presented in brief. Gliptins have also been compared with SUs (glimepiride, glipizide, gliclazide) [27-34], TZDs (pioglitazone $30 \mathrm{mg}$, rosiglitazone $8 \mathrm{mg}$ ) [35-39] and GLP-1 receptor agonists (exenatide, liraglutide) [36,40,41]. However, only one head-to-head study compared two different DPP-4 inhibitors in the same trial: saxagliptin $5 \mathrm{mg}$ with sitaglitptin $100 \mathrm{mg}$ as add-ons to basal metformin therapy [42].

Compared with SU, a DPP-4 inhibitor generally led to a similar reduction in $\mathrm{HbA}_{1 \mathrm{c}}$ levels and a similar increase in the proportion of patients achieving $\mathrm{HbA}_{1 \mathrm{c}}$ levels $<7 \%(53 \mathrm{mmol} / \mathrm{mol}$; Table 2, Fig. 1), but with a much lower incidence of hypoglycaemic events. SU therapy was associated with modest weight gain, whereas the administration of a gliptin resulted in no weight change or even modest weight loss (Table 1, Fig. 1). In the two longest-running trials, the 'escape phenomenon', assessed by a secondary increase in $\mathrm{HbA}_{1 \mathrm{c}}$ levels between weeks 24 and 104 following a good initial $\mathrm{HbA}_{1 \mathrm{c}}$ reduction, was significantly less pronounced with sitagliptin $100 \mathrm{mg}$ or vildagliptin $100 \mathrm{mg}$ than with glipizide or glimepiride, respectively [28,31], suggesting better $\beta$-cell protection and durability of glucose control with a DPP-4 inhibitor.

Compared with a TZD, a DPP-4 inhibitor was not inferior as regards improvement of glucose control (Table 2, Fig. 1). Initial observations had suggested that DPP-4 inhibitors might be less potent than TZDs. However, when considering the results of different trials in indirect comparisons, it is crucial to adjust treatment-induced $\mathrm{HbA}_{1 \mathrm{c}}$ reductions in relation to baseline values $[43,44]$. In this case, the differences between gliptins and TZDs that had initially appeared almost disappeared and, thus, were in agreement with the head-to-head comparisons analyzed in the present report. However, there was a clear-cut difference between the two pharmacological classes in terms of body-weight changes. A significant weight increase was observed in all trials with TZDs in contrast to the weight neutrality seen with DPP-4 inhibitors (Table 2, Fig. 1).

\subsection{Gliptins in special combinations}

\subsubsection{Gliptins combined with sulphonylureas}

Several trials have evaluated the efficacy and safety of adding a DPP-4 inhibitor vs a placebo to SU monotherapy (glimepiride or glyburide). This may be of interest in patients who cannot be treated with metformin. Compared with a placebo, sitagliptin $100 \mathrm{mg}$ (once daily) [45] and vildagliptin (50 or $100 \mathrm{mg}$ daily) [46] significantly 
improved glycaemic control and $\beta$-cell function, and were well tolerated in T2DM patients with inadequate glycaemic control with glimepiride alone. Similar results were reported in T2DM patients with the addition of alogliptin (12.5 mg or $25 \mathrm{mg}$ ) to glyburide [47] and the addition of linagliptin (5mg) to a SU [48]. In addition, saxagliptin (2.5 or $5 \mathrm{mg}$ ) added to submaximum glyburide $(5$ or $7.5 \mathrm{mg}$ ) therapy led to statistically significant improvements vs upti-tration of glyburide alone (up to $15 \mathrm{mg}$ ) across key glycaemic parameters, with no significant differences in the reported incidences of hypoglycaemic events after a follow-up of 24 weeks [49] and 76 weeks [50]. However, while the association of gliptin-metformin did not lead to hypoglycaemia, hypoglycaemic events may arise with the combination of gliptin-SU. This means that, in T2DM patients with moderately increased $\mathrm{HbA}_{1 \mathrm{c}}$ levels taking $\mathrm{SU}$ as monotherapy, it may be safer to reduce the SU dose when a DPP-4 inhibitor is added to minimize the risk of hypoglycaemia, especially in elderly patients.

Table 1 : Head-to-head trials comparing a DPP-4 inhibitor and an active glucose-lowering agent (metformin, a thiazolidinedione or acarbose) in drug-naive type 2 diabetes mellitus (T2DM) patients.

\begin{tabular}{|c|c|c|c|c|c|c|c|}
\hline & Reference & $n$ & $\begin{array}{c}\text { Period } \\
\text { (weeks) }\end{array}$ & $\begin{array}{c}\text { Intervention } \\
\text { (mg/day) }\end{array}$ & $\begin{array}{c}\Delta \mathbf{H b A}_{1 \mathrm{c}} \\
(\%)\end{array}$ & $\begin{array}{l}\mathrm{HbA}_{1 \mathrm{c}}<7 \% \%^{\mathrm{a}} \\
(\% \text { patients) }\end{array}$ & $\begin{array}{c}\Delta \mathrm{BW} \\
(\mathrm{kg})\end{array}$ \\
\hline \multirow[t]{11}{*}{ Sitagliptin } & \multirow[t]{3}{*}{ Goldstein et al., 2007 [13] } & \multirow[t]{3}{*}{1091} & \multirow[t]{3}{*}{24} & Sitagliptin 100 & -0.66 & 20 & 0 \\
\hline & & & & Metformin 1000 & -0.82 & 23 & -0.6 \\
\hline & & & & Metformin 2000 & -1.13 & 38 & -1.3 \\
\hline & \multirow{3}{*}{ Williams-Herman et al., 2009 [14] } & \multirow[t]{3}{*}{885} & \multirow[t]{3}{*}{54} & Sitagliptin 100 & -0.80 & 23 & +0.6 \\
\hline & & & & Metformin 1000 & -1.00 & 25 & -1.0 \\
\hline & & & & Metformin 2000 & -1.30 & 44 & -1.5 \\
\hline & \multirow[t]{3}{*}{ Williams-Herman et al., 2010 [15] } & \multirow[t]{3}{*}{454} & \multirow[t]{3}{*}{104} & Sitagliptin 100 & -1.20 & 32 & +0.5 \\
\hline & & & & Metformin 1000 & -1.10 & 28 & -0.8 \\
\hline & & & & Metformin 2000 & -1.30 & 45 & -2.4 \\
\hline & \multirow[t]{2}{*}{ Aschner et al., 2010 [16] } & \multirow[t]{2}{*}{1050} & \multirow[t]{2}{*}{24} & Sitagliptin 100 & -0.43 & 69 & -0.6 \\
\hline & & & & Metformin 2000 & -0.57 & 76 & -1.9 \\
\hline \multirow[t]{14}{*}{ Vildagliptin } & \multirow[t]{2}{*}{ Schweizer et al., 2007 [12] } & \multirow[t]{2}{*}{780} & \multirow[t]{2}{*}{52} & Vildagliptin 100 & -1.0 & 35 & +0.3 \\
\hline & & & & Metformin 2000 & -1.4 & 45 & -1.9 \\
\hline & \multirow[t]{2}{*}{ Göke et al., 2008 [17] } & \multirow[t]{2}{*}{305} & \multirow[t]{2}{*}{104} & Vildagliptin 100 & -1.0 & NA & +0.5 \\
\hline & & & & Metformin 2000 & -1.5 & NA & -2.5 \\
\hline & \multirow[t]{2}{*}{ Schweizer et al., 2009 [18] } & \multirow[t]{2}{*}{335} & \multirow[t]{2}{*}{24} & Vildagliptin 100 & -0.64 & 49 & -0.45 \\
\hline & & & & Metformin 1500 & -0.75 & 61 & -1.25 \\
\hline & \multirow[t]{2}{*}{ Bosi et al.,2009 [19] } & \multirow[t]{2}{*}{589} & \multirow[t]{2}{*}{24} & Vildagliptin 100 & -1.1 & 40 & -0.59 \\
\hline & & & & Metformin 2000 & -1.4 & 44 & -1.62 \\
\hline & \multirow[t]{2}{*}{ Rosenstock et al., 2007 [24] } & \multirow[t]{2}{*}{786} & 24 & Vildagliptin 50 & -1.1 & NA & -0.3 \\
\hline & & & & Rosiglitazone 8 & -1.3 & NA & +1.6 \\
\hline & Rosenstock et al., 2007 [22] & 607 & 24 & Vildagliptin 100 & -1.1 & 42 & +0.2 \\
\hline & & & & Pioglitazone 30 & -1.4 & 43 & +1.5 \\
\hline & Pan et al., 2008 [25] & 661 & 24 & Vildagliptin 100 & -1.4 & 46 & -0.4 \\
\hline & & & & Acarbose (up to 300 ) & -1.3 & 47 & -1.7 \\
\hline Saxagliptin & Jadzinsky et al., 2009 [20] & 663 & 24 & Saxagliptin 10 & -1.7 & 32 & -1.1 \\
\hline & & & & Metformin 500-2000 & -2.0 & 41 & -1.6 \\
\hline & Pfützner et al., 2011 [21] & 428 & 76 & Saxagliptin 10 & -1.55 & 25 & -0.3 \\
\hline & & & & Metformin 500-2000 & -1.79 & 35 & -1.0 \\
\hline Alogliptin & Rosenstock et al., 2010 [23] & 327 & 26 & Alogliptin 25 & -0.96 & 24 & -0.3 \\
\hline & & & & Pioglitazone 30 & -1.15 & 34 & +2.2 \\
\hline Linagliptin & Kawamori et al., 2010 [26] & 481 & 26 & Linagliptin 5 & -0.44 & 30 & NA \\
\hline & & & & Linagliptin 10 & -0.48 & 34 & NA \\
\hline & & & & Voglibose 0.6 & -0.10 & 22 & NA \\
\hline
\end{tabular}

\subsubsection{Gliptins combined with thiazolidinediones}

Given the pathophysiology of T2DM, the combination of an insulin secretagogue, such as a DPP-4 inhibitor, and an insulin sensitizer, such as TZD, may appear to be an appealing approach [51]. In fact, each of the five studied DPP-4 inhibitors was able to further reduce $\mathrm{HbA}_{1 \mathrm{c}}$ levels by almost $1 \%$ and increase the proportion of patients 
with $\mathrm{HbA}_{1 \mathrm{c}}$ levels $<7 \%$ (53 $\left.\mathrm{mmol} / \mathrm{mol}\right)$ by $15-20 \%$ when added to pioglitazone, without increasing hypoglycaemic episodes and with minimal weight increases (Table 3). All these studies compared the effect of adding a DPP-4 inhibitor vs a placebo [52-58].

Only one study used an active comparator instead of a placebo to evaluate the DPP-4 inhibitor added to TZD. In this controlled trial, the effects of the addition of sitagliptin (100 mg once a day) or metformin ( $850 \mathrm{mg}$ twice a day) to pioglitazone monotherapy in poorly controlled T2DM patients showed improvements in $\mathrm{HbA}_{1 \mathrm{c}}$, fasting plasma glucose and postprandial glucose levels with both interventions. However, metformin also led to a decrease in body weight, and to faster and better improvements in insulin resistance and inflammatory state parameters, even though sitagliptin led to better protection of $\beta$-cell function. However, an important limitation of the study was that the dose of piogliazone was different between the two arms (15 $\mathrm{mg}$ with metformin and 30 mg with sitagliptin; Table 3) [59]. In another study from the same group, a pioglitazone plus vildagliptin combination was more effective in preserving $\beta$-cell function, and reducing insulin resistance and inflammatory state parameters, despite similar improvements in glucose control parameters compared with the glimepiride plus vildagliptin combination [60].

Thus, the combination of a DPP-4 inhibitor with piogli-tazone may be an effective and safe therapeutic approach in patients with T2DM who cannot tolerate either metformin or SU [61].

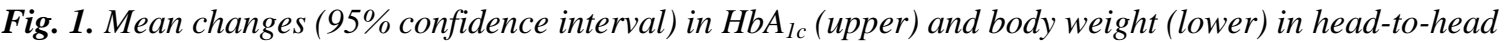
trials comparing a gliptin and metformin in drug-naive patients (10 trials), a gliptin and a sulphonylurea (SU) in metformin-treated patients (eight trials), and a gliptin and a glitazone (TZD) in both drug-naive and metformintreated patients (eight trials). P values are for between-treatment differences. Note that some trials were computed twice or three times, as specific reports were published after various follow-up durations (24, 54 and/or 104 weeks).

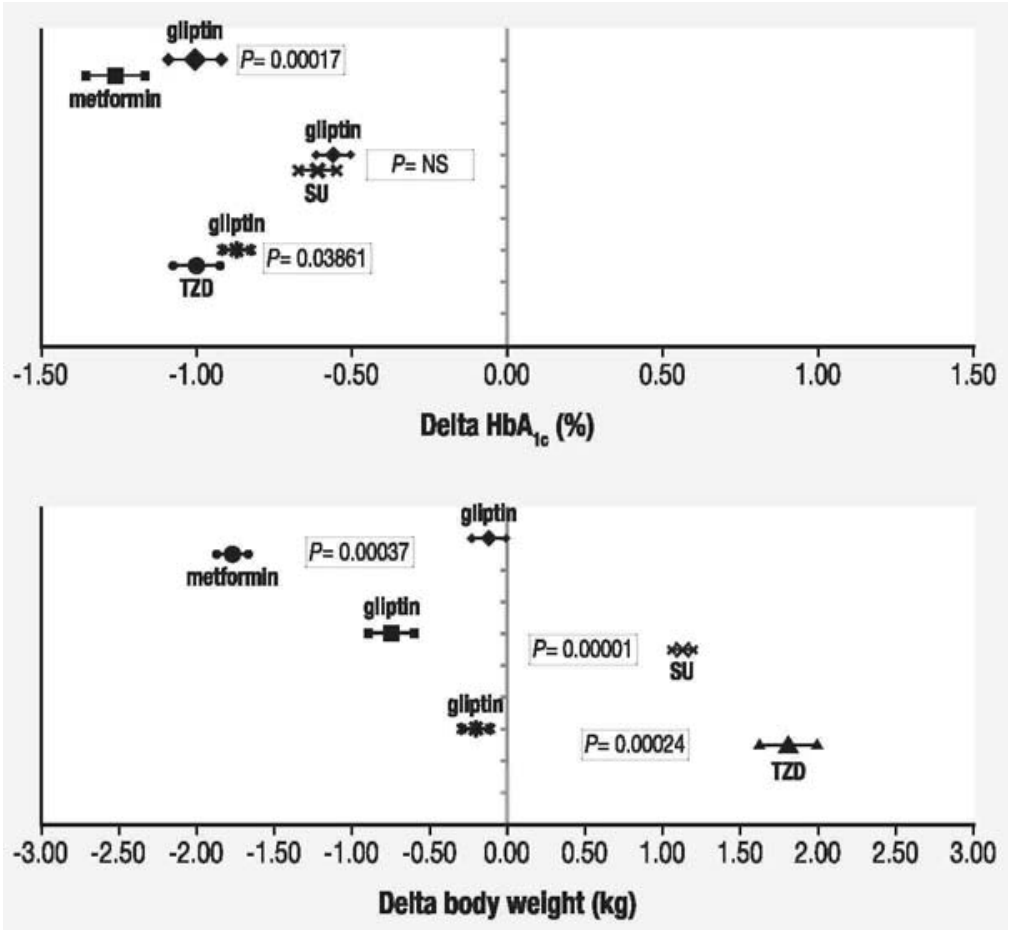

Table 2 : Head-to-head trials comparing a DPP-4 inhibitor and an active glucose-lowering agent (sulphonylurea, thiazolidinedione, exenatide or liraglutide), and one trial of sitagliptin vs saxagliptin, in type 2 diabetes mellitus (T2DM) patients already treated with metformin ( $\geq 1500 \mathrm{mg} /$ day).

\begin{tabular}{|c|c|c|c|c|c|c|c|}
\hline & Reference & $n$ & $\begin{array}{c}\text { Period } \\
\text { (weeks) }\end{array}$ & $\begin{array}{c}\text { Intervention } \\
\text { (mg/day) }\end{array}$ & $\begin{array}{c}\Delta \mathbf{H b A}_{1 \mathrm{c}} \\
(\%)\end{array}$ & $\begin{array}{l}\mathrm{HbA}_{1 \mathrm{c}}<7 \%{ }^{\mathrm{a}} \\
\text { (\% patients) }\end{array}$ & $\begin{array}{c}\Delta \mathbf{B W} \\
(\mathbf{k g})\end{array}$ \\
\hline \multirow[t]{4}{*}{ Sitagliptin } & Nauck et al., 2007 [27] & 1172 & 52 & Sitagliptin 100 & -0.67 & 63 & -1.5 \\
\hline & & & & Glipizide 5-20 & -0.67 & 59 & +1.1 \\
\hline & Seek et al., 2010 [28] & 1172 & 104 & Sitagliptin 100 & -0.54 & 63 & -1.6 \\
\hline & & & & Glipizide $5-20$ & -0.51 & 59 & +0.7 \\
\hline
\end{tabular}




\begin{tabular}{|c|c|c|c|c|c|c|c|}
\hline & Arechavaleta et al., 2011 [29] & 1035 & 30 & Sitagliptin 100 & -0.47 & 52 & -0.8 \\
\hline & & & & Glimepiride 1-6 & -0.54 & 60 & +1.2 \\
\hline & Scott et al., 2008 [35] & 273 & 18 & Sitagliptin 100 & -0.73 & 55 & -0.4 \\
\hline & & & & Rosiglitazone 8 & -0.79 & 63 & +1.5 \\
\hline & Bergenstal et al., 2010 [36] & 514 & 26 & Sitagliptin 100 & -0.9 & 30 & -0.8 \\
\hline & & & & Pioglitazone 45 & -1.2 & 43 & +2.8 \\
\hline & & & & $\begin{array}{c}\text { Exenatide } 2 \\
\text { once weekly sc }\end{array}$ & -1.5 & 59 & -2.3 \\
\hline & Pratley et al., 2010 [40] & 665 & 26 & Sitagliptin 100 & -0.9 & 21 & -0.96 \\
\hline & & & & Liraglutide 1.2 & -1.24 & 44 & -2.86 \\
\hline & & & & Liraglutide 1.8 & -1.50 & 55 & -3.38 \\
\hline & Pratley et al., 2011 [41] & 497 & 52 & Sitagliptin 100 & -0.88 & 27 & -1.16 \\
\hline & & & & Liraglutide 1.2 & -1.29 & 50 & -2.78 \\
\hline & & & & Liraglutide 1.8 & -1.51 & 63 & -3.68 \\
\hline Vildagliptin & Ferrannini et al., 2009 [30] & 2789 & 52 & Vildagliptin 100 & -0.44 & 54 & -0.2 \\
\hline & & & & Glimepiride 1-6 & -0.53 & 56 & +1.6 \\
\hline & Matthews et al., 2010 [31] & 3118 & 104 & Vildagliptin 100 & -0.1 & 37 & -0.3 \\
\hline & & & & Glimepiride 1-6 & -0.1 & 38 & +1.2 \\
\hline & Filozof et al.,2010 [32] & 1007 & 52 & Vildagliptin 100 & -0.81 & 30 & +0.08 \\
\hline & & & & Gliclazide $80-320$ & -0.85 & 32 & +1.36 \\
\hline & Bolli et al., 2008 [37] & 576 & 24 & Vildagliptin 100 & -0.9 & 27 & +0.3 \\
\hline & & & & Pioglitazone 30 & -1.0 & 36 & +1.9 \\
\hline & Bolli et al., 2009 [38] & 576 & 52 & Vildagliptin 100 & -0.6 & NA & +0.2 \\
\hline & & & & Pioglitazone 30 & -0.6 & NA & +2.6 \\
\hline & Blonde et al., 2009 [39] & 2478 & 12 & Vildagliptin 100 & -0.68 & 60 & -0.6 \\
\hline & & & & TZD (variable) & -0.57 & 52 & +0.3 \\
\hline Saxagliptin & Göke et al., 2010 [33] & 858 & 52 & Saxagliptin 5 & -0.74 & 43 & -1.1 \\
\hline & & & & Glipizide 5-20 & -0.80 & 48 & +1.1 \\
\hline Alogliptin & No published trial & & & & & & \\
\hline Linagliptin & Forst et al., 2010 [34] & 333 & 12 & Linagliptin 1 & -0.40 & 15 & -0.15 \\
\hline & & & & Linagliptin 5 & -0.73 & 15 & -0.57 \\
\hline & & & & Linagliptin 10 & -0.67 & 21 & -1.27 \\
\hline & & & & Glimepiride 1-3 & -0.90 & NA & +0.73 \\
\hline Saxa- vs & Scheen et al.,2010[42] & 801 & 18 & Sitagliptin 100 & -0.62 & 39 & -0.4 \\
\hline Sitagliptin & & & & Saxagliptin 5 & -0.52 & 33 & -0.4 \\
\hline
\end{tabular}

$\Delta$ : change vs baseline; BW: body weight; se: subcutaneous; NA: not available; TZD: thiazolidinedione (pioglitazone or rosiglitazone). ${ }^{\text {a }} 53$ $\mathrm{mmol} / \mathrm{mol}$.

Table 3 : Head-to-head trials comparing a DPP-4 inhibitor and a placebo or an active glucose-lowering agent (uptitration of initial dose of sulphonylurea [SU] or metformin) in type 2 diabetes mellitus (T2DM) patients already treated with a SU or a thiazolidinedione (TZD).

\begin{tabular}{|c|c|c|c|c|c|c|c|c|}
\hline & Reference & $n$ & $\begin{array}{c}\text { Period } \\
\text { (weeks) }\end{array}$ & $\begin{array}{l}\text { Baseline } \\
\text { (mg/day) }\end{array}$ & $\begin{array}{c}\text { Intervention } \\
\text { (mg/day) }\end{array}$ & $\begin{array}{c}\Delta \mathbf{H b A}_{1 \mathrm{c}} \\
(\%)\end{array}$ & $\begin{array}{l}\mathrm{HbA}_{1 \mathrm{c}}<7 \% \%^{\mathrm{a}} \\
(\% \text { patients) }\end{array}$ & $\begin{array}{c}\Delta B W \\
(\mathrm{~kg})\end{array}$ \\
\hline \multicolumn{9}{|l|}{ Add-on to SU } \\
\hline \multirow[t]{2}{*}{ Sitagliptin } & Hermansen et al., 2007 [45] & 212 & 24 & Glimepiride & Sita 100 & -0.30 & 11 & +1.1 \\
\hline & & & & $\geq 4$ & Placebo & +0.27 & 9 & 0 \\
\hline \multirow[t]{3}{*}{ Vildagliptin } & Garber et al.,2008 [46] & 515 & 24 & Glimepiride 4 & Vilda 50 & -0.58 & 21 & -0.1 \\
\hline & & & & & Vilda 100 & -0.63 & 25 & +1.3 \\
\hline & & & & & Placebo & +0.07 & 12 & -0.4 \\
\hline \multirow[t]{6}{*}{ Saxagliptin } & Chacra et al.,2009 [49] & 768 & 24 & Glyburide 7.5 & Saxa 2.5 & -0.54 & 22 & +0.7 \\
\hline & & & & & Saxa 5 & -0.64 & 23 & +0.8 \\
\hline & & & & & SU uptitration 15 & +0.08 & 9 & +0.3 \\
\hline & Chacra et al.,2011 [50] & 557 & 76 & Glyburide 7.5 & Saxa 2.5 & +0.11 & 27 & +0.8 \\
\hline & & & & & Saxa 5 & +0.03 & 24 & +1.0 \\
\hline & & & & & SU uptitration 15 & +0.69 & 14 & +0.3 \\
\hline \multirow[t]{3}{*}{ Alogliptin } & Pratley et al., 2009 [47] & 500 & 26 & Glyburide $\geq 10$ & Alo 12.5 & -0.38 & 30 & +0.6 \\
\hline & & & & & Alo 25 & -0.52 & 35 & +0.7 \\
\hline & & & & & Placebo & +0.01 & 18 & -0.2 \\
\hline
\end{tabular}




\begin{tabular}{|c|c|c|c|c|c|c|c|c|}
\hline Linagliptin & Lewin et al., 2010 [48] & 240 & 18 & SU (variable) & $\begin{array}{c}\text { Lina } 5 \\
\text { Placebo }\end{array}$ & $\begin{array}{l}-0.57 \\
-0.10\end{array}$ & $\begin{array}{c}15 \\
4\end{array}$ & $\begin{array}{l}\approx 0 \\
\approx 0\end{array}$ \\
\hline Add-on to $T Z$ & & & & & & & & \\
\hline Sitagliptin & Rosenstock et al., 2006 [52] & 175 & 24 & Pioglitazone $30-45$ & Sita 100 & -0.85 & 45 & +1.8 \\
\hline & & & & & Placebo & -0.15 & 23 & +1.5 \\
\hline & Derosa et al., 2010 [59] & 151 & 52 & Pioglitazone 30 & Sita 100 & -1.4 & NA & -1.6 \\
\hline & & & & Pioglitazone 15 & Metformin 1700 & -1.4 & NA & -2.8 \\
\hline Vildagliptin & Garber et al.,2007[53] & 463 & 24 & Pioglitazone 45 & Vilda 50 & -0.8 & 29 & +1.5 \\
\hline & & & & & Vilda 100 & -1.0 & 36 & +2.7 \\
\hline & & & & & Placebo & -0.3 & 15 & +1.4 \\
\hline Saxagliptin & Hollander et al., 2009 [54] & 565 & 24 & TZD (variable) ${ }^{\mathrm{b}}$ & Saxa 2.5 & -0.66 & 42 & +1.3 \\
\hline & & & & & Saxa 5 & -0.94 & 42 & +1.4 \\
\hline & & & & & Placebo & -0.30 & 26 & +0.9 \\
\hline & Hollander et al., 2011 [57] & 360 & 76 & TZD (variable) $)^{\mathrm{b}}$ & Saxa 2.5 & -0.59 & 35 & +2.0 \\
\hline & & & & & Saxa 5 & -1.09 & 41 & +2.2 \\
\hline & & & & & Placebo & -0.2 & 24 & +1.6 \\
\hline Alogliptin & Pratley et al., 2009 [55] & 493 & 26 & Pioglitazone $30-45$ & Alo 12.5 & -0.66 & NA & NA \\
\hline & & & & & Alo 25 & -0.80 & NA & NA \\
\hline & & & & & Placebo & -0.19 & NA & NA \\
\hline & Kaku et al., 2011 [56] & 329 & 12 & Pioglitazone 15-30 & Alo 12.5 & -0.91 & 49 & +0.5 \\
\hline & & & & & Alo 25 & -0.97 & 50 & +0.5 \\
\hline & & & & & Placebo & -0.19 & 20 & 0 \\
\hline Linagliptin & Gomis et al., 2011 [58] & 389 & 24 & Pioglitazone $30^{c}$ & Lina 5 & -1.06 & 43 & +2.3 \\
\hline & & & & & Placebo & -0.56 & 30 & +1.2 \\
\hline
\end{tabular}

$\Delta$ : change $v$ s baseline; BW: body weight; NA: not available. ${ }^{\text {a }} 53 \mathrm{mmol} / \mathrm{mol}$.

${ }^{\mathrm{b}}$ pioglitazone $30-45 \mathrm{mg}$ or rosiglitazone $4-8 \mathrm{mg} .{ }^{\mathrm{c}} \mathrm{TZD}$ as initial treatment.

\subsubsection{Gliptins as oral triple therapy}

The arrival of DPP-4 inhibitors offered a new alternative for oral triple therapy (Table 4) at a time when only the combination of metformin plus SU plus TZD was available [62]. Again, most studies, except one [63], were randomized clinical trials comparing the addition of a gliptin $v s$ a placebo on top of a dual combination of either metformin-SU [45,64] or metformin-TZD [65]. Sitagliptin 100mg once daily significantly improved glycaemic control and $\beta$-cell function in patients with T2DM who had inadequate glycaemic control with glimepiride plus metformin therapy [45]. Similarly, adding linagliptin $5 \mathrm{mg}$ to metformin in combination with SU significantly improved glycaemic control in T2DM patients and was well tolerated [64]. Adding alogliptin $25 \mathrm{mg}$ to a metformin-pioglitazone regimen provided superior glycaemic control and potentially improved $\beta$-cell function vs uptitrating pioglitazone in T2DM patients, with no clinically important differences in safety [65]. One study compared two modalities of triple therapy. Among ethnic-minority T2DM patients poorly controlled with the maximum tolerated doses of metformin and SU, third-line add-on therapy with TZD (rosiglitazone 8mg or pioglitazone $45 \mathrm{mg}$ ) was found to control hyperglycaemia more effectively than sitagliptin $100 \mathrm{mg}$ after 4 months [63].

Table 4 : Head-to-head trials comparing a DPP-4 inhibitor and an active glucose-lowering agent in type 2 diabetes mellitus (T2DM) patients already treated with a combined oral therapy [sulphonylurea (SU) + metformin or SU + thiazolidinedione (TZD)] or insulin (with or without metformin).

\begin{tabular}{|c|c|c|c|c|c|c|c|c|}
\hline & Reference & $n$ & $\begin{array}{l}\text { Period } \\
\text { (weeks) }\end{array}$ & Baseline & $\begin{array}{c}\text { Intervention } \\
\text { (mg/day) }\end{array}$ & $\begin{array}{c}\Delta \mathbf{H b A}_{1 \mathbf{c}} \\
(\%)\end{array}$ & $\begin{array}{l}\mathrm{HbA}_{1 \mathrm{c}}<7 \% \%^{\mathrm{a}} \\
\text { (\%patients) }\end{array}$ & $\begin{array}{c}\Delta \mathbf{B W} \\
(\mathrm{kg})\end{array}$ \\
\hline \multicolumn{9}{|c|}{ Triple therapy } \\
\hline \multirow[t]{3}{*}{ Sitagliptin } & Hermansen et al., 2007 [45] & 229 & 24 & Metformin + glimepiride & Sita 100 & -0.59 & 231 & +0.4 \\
\hline & Hsia et al., 2011 [63] & 212 & 16 & Metformin $+\mathrm{SU}$ & Sita 100 & -1.3 & $46^{\mathrm{b}}$ & +1.1 \\
\hline & & & & & TZD & -2.0 & $62^{\mathrm{b}}$ & NA \\
\hline Vildagliptin & No published trial & & & & & & & \\
\hline & & & & & Placebo & -0.29 & & +1.6 \\
\hline
\end{tabular}




\begin{tabular}{|c|c|c|c|c|c|c|c|c|}
\hline Linagliptin & Owens et al., 2011 [64] & 1058 & 24 & Metformin + SU & $\begin{array}{l}\text { Lina } 5 \\
\text { Placebo }\end{array}$ & $\begin{array}{l}-0.72 \\
-0.10\end{array}$ & 298 & $\begin{array}{l}+0.27 \\
-0.06\end{array}$ \\
\hline \multicolumn{9}{|c|}{ Add-on to insulin } \\
\hline Sitagliptin & Visboll et al., 2010 [67] & 641 & 24 & Insulin & $\begin{array}{l}\text { Sita } 100 \\
\text { Placebo }\end{array}$ & -0.60 & $\begin{array}{c}13 \\
5\end{array}$ & $\begin{array}{l}+0.1 \\
+0.1\end{array}$ \\
\hline Vildagliptin & Fonseca et al.,2007 [66] & 296 & 24 & Insulin $\geq 30$ units & $\begin{array}{l}\text { Vilda } 100 \\
\text { Placebo }\end{array}$ & $\begin{array}{l}-0.5 \\
-0.2\end{array}$ & $\begin{array}{l}\text { NA } \\
\text { NA }\end{array}$ & $\begin{array}{l}+1.3 \\
+0.6\end{array}$ \\
\hline Saxagliptin & Barnett et al., 2011 [69] & 455 & 52 & $\begin{array}{c}\text { Insulin } \\
30-150 \text { units }\end{array}$ & $\begin{array}{c}\text { Saxa } 5 \\
\text { Placebo }\end{array}$ & $\begin{array}{l}-0.80 \\
-0.40\end{array}$ & $\begin{array}{c}21 \\
9\end{array}$ & $\begin{array}{l}+0.8 \\
+0.5\end{array}$ \\
\hline Alogliptin & Rosenstock et al., 2009 [68] & 390 & 26 & Insulin \pm metformin & $\begin{array}{c}\text { Alo } 12.5 \\
\text { Alo } 25 \\
\text { Placebo }\end{array}$ & $\begin{array}{l}-0.63 \\
-0.71 \\
-0.13\end{array}$ & $\begin{array}{l}\text { NA } \\
\text { NA } \\
\text { NA }\end{array}$ & $\begin{array}{l}+0.68 \\
+0.60 \\
+0.63\end{array}$ \\
\hline
\end{tabular}

$\Delta$ : change vs baseline; BW: body weight; NA: not available. ${ }^{a} 53 \mathrm{mmol} / \mathrm{mol}{ }^{b}<7.5 \%(58 \mathrm{mmol} / \mathrm{mol}) \mathrm{instead} \mathrm{of}<7 \%(53 \mathrm{mmol} / \mathrm{mol})$.

\subsubsection{Gliptins combined with insulin in type 2 diabetes mellitus}

Insulin therapy in T2DM patients is frequently initiated while oral glucose-lowering agents (most often metformin, sometimes SU) are maintained, at least in part. Therefore, it may also be possible to speculate on the clinical efficacy of combining a DPP-4 inhibitor with insulin. Four placebo-controlled trials have investigated the clinical efficacy and safety of adding a DPP-4 inhibitor to a basal insulin regimen (with or without metformin or SU; Table 4) [66-69]. All studies reported consistent results, with a reduction in $\mathrm{HbA}_{1 \mathrm{c}}$ levels of $0.5-0.6 \%$ on average if daily insulin dosages were maintained unchanged. These favourable results were obtained with no weight gains or increases in the incidence of hypoglycaemia. A reduction in severe hypoglycaemic episodes was reported in one trial of insulin plus vildagliptin in T2DM patients poorly controlled with high doses of insulin, presumably because of an individual reduction in daily insulin dosage (which resulted in a smaller $\mathrm{HbA}_{1 \mathrm{c}}$ reduction of only $0.3 \%$ ) [66]. In the TRANSITION randomized controlled trial [70], significantly greater reductions in $\mathrm{HbA}_{1 \mathrm{c}}(-1.44 \%$ vs $-0.89 \% ; P<0.001)$ and plasma glucose levels were achieved with the combination of insulin detemir + sitagliptin + metformin compared with sitagliptin + metformin $\pm \mathrm{SU}$, with no increases in the rate of hypoglycaemia.

Thus, adding a DPP-4 inhibitor to insulin therapy may be useful in T2DM patients for improving glucose control without increasing hypoglycaemia, and possibly for limiting weight gain. Further studies are warranted to explore the role of a DPP-4 inhibitor added to optimized insulin regimens (premixed insulin preparations or a basal-bolus insulin scheme), as the available studies only involved patients using basal insulin therapy.

\subsection{Gliptins as the initial combination}

Because of the complexity of the pathophysiology of T2DM and the frequently observed primary or secondary failure of monotherapy, initial combination treatment may be considered to offer more efficacious management of T2DM [51]. Several clinical trials have evaluated initial combinations of either metformin + gliptin [13-15,19$21,71]$ or TZD + gliptin $[22,23,58,72]$ and compared the results with an initial monotherapy (Table 1). However, none of these trials evaluated an initial combination including a DPP-4 inhibitor vs another initial combination not including a gliptin in a head-to-head comparison.

The initial combination of sitagliptin $(2 \times 50 \mathrm{mg})$ or vildagliptin $(2 \times 50 \mathrm{mg})$ with metformin (low dose of $2 \times$ $500 \mathrm{mg}$ or high dose of $2 \times 1000 \mathrm{mg}$ ) had superior efficacy compared with monotherapy treatments, with comparable overall tolerability profiles and low risk of hypoglycaemia [13-15,19-21,71]. Similar results were obtained with the initial combination of saxagliptin 5 or $10 \mathrm{mg}$ plus metformin $500 \mathrm{mg}$ uptitrated to $2000 \mathrm{mg}$ $[20,21]$. These favourable results were observed in both short-term (18-24 weeks) and long-term (54-104 weeks) clinical trials. The potential dose-sparing effect of adding a DPP-4 inhibitor to relatively low-dose metformin in preference to metformin uptitration may allow patients to achieve equivalent or superior $\mathrm{HbA}_{1 \mathrm{c}}$-lowering without the gastrointestinal tolerability issues associated with higher doses of metformin [73].

Similar results have been reported with the initial combination of TZD-gliptin [22,23,58,72]. Reductions in $\mathrm{HbA}_{1 \mathrm{c}}$ of $1-2.4 \%$ vs baseline have been reported and were always significantly greater than those observed with monotherapy with either TZD or a DPP-4 inhibitor. In addition, first-line combined treatments had minimal risks of hypoglycaemia, led to similar or only slightly more weight gain than pioglitazone on its own and offered a tolerability profile comparable to component monotherapy. Thus, such combinations may offer a valuable adjunctive initial treatment option for T2DM, particularly in cases where metformin is contraindicated, as in patients with renal impairment. 


\subsection{Head-to-head trials comparing incretin-based therapies}

\subsubsection{DPP-4 inhibitors vs GLP-1 receptor agonists}

Incretin-based agents include GLP-1 receptor agonists, which mimic endogenous GLP-1, and DPP-4 inhibitors, which inhibit the breakdown of endogenous incretin hormones [74,75]. This means that both GLP-1 receptor agonists and DPP-4 inhibitors elevate GLP-1 activity and substantially improve glycaemic control. Indirect comparisons reported in meta-analyses of randomized controlled trials have shown that GLP-1 receptor agonists are more effective in lowering blood glucose and result in substantial weight loss, whereas therapy with DPP-4 inhibitors lowers blood glucose levels to a lesser degree and is weight-neutral [8]. However, head-to-head comparisons of the two therapies are scarce, and only one DPP-4 (sitagliptin) has been so evaluated. Two trials compared sitagliptin $100 \mathrm{mg}$ vs exenatide either twice daily [76] or once weekly [36], and a further trial compared sitagliptin $100 \mathrm{mg}$ with liraglutide once daily [40] (Table 2).

In a trial comparing short-term (2-week) treatment with exenatide ( $5 \mu \mathrm{g}$ twice daily for $1 \mathrm{week}$, then $10 \mu \mathrm{g}$ twice daily for 1 week) vs sitagliptin $100 \mathrm{mg}$ once daily, the results were better with exenatide treatment, as assessed in terms of lowering postprandial glucose, increasing insulin levels, decreasing glucagon levels and decreasing caloric intakes [76]. A 26-week, randomized, double-dummy superiority trial assessed the safety and efficacy of exenatide $2 \mathrm{mg}$ once a week vs sitagliptin $100 \mathrm{mg}$ once a day in patients treated with metformin. Treatment with exenatide reduced $\mathrm{HbA}_{1 \mathrm{c}}$ significantly more than did sitagliptin, with greater weight loss and no episodes of major hypoglycaemia (Table 2). However, exenatide was associated with more nausea and diarrhoea than sitagliptin [36]. Also, an extension of the study showed that patients who switched to once-weekly exenatide from daily sitagliptin had improved or sustained glycaemic control $\left(\mathrm{HbA}_{1 \mathrm{c}}-0.3 \%\right)$ and weight loss $(-1.1 \%)$ [77]. In a 24-week prospective trial comparing treatment with liraglutide (1.2 or $1.8 \mathrm{mg}$ once daily) vs sitagliptin 100 $\mathrm{mg}$ in metformin-treated patients with $\mathrm{T} 2 \mathrm{DM}$, reductions in $\mathrm{HbA}_{1 \mathrm{c}}$ and body weight were significantly greater with both dosages of liraglutide than with sitagliptin, but at the cost of an increased incidence of minor sideeffects such as nausea and vomiting (Table 2) [40]. Incidences of hypoglycaemic events were low (5\%) and similar in all treatment groups. These data were also confirmed after 1 year [41].

Although GLP-1 receptor agonists demonstrate superiority compared with DPP-4 inhibitors, the average modest differences in $\mathrm{HbA}_{1 \mathrm{c}}$ and weight reductions may be counterbalanced by several disadvantages of GLP-1 receptor agonists (injected vs oral, more nausea, more expensive). Other possible additional advantages remain to be demonstrated, such as better cardiovascular protection and longer duration of glucose control [5,74,75].

\subsubsection{Head-to-head comparisons among gliptins}

As DPP-4 inhibitors have heterogeneous chemical structures and various pharmacokinetic characteristics, this raises the question of possible between-gliptin differences in efficacy and safety profiles [78]. The different DPP-4 inhibitors are distinctive in their metabolism (saxagliptin and vildagliptin are metabolized in the liver whereas sitagliptin is not), excretion (linagliptin is excreted mostly unchanged by the liver, unlike other DPP-4 inhibitors, which are mainly eliminated via the kidneys) and potential for cytochrome-mediated drug-drug interactions (observed with saxagliptin, but not with other gliptins). Certain of these differences may be clinically relevant, especially in patients with renal impairment (see below). Nevertheless, all DPP-4 inhibitors are similar when comparing their mode of action (as 'incretin enhancers'), efficacy in lowering $\mathrm{HbA}_{1 \mathrm{c}}$ levels, safety profile (no risk of severe hypoglycaemia) and patient tolerability. Also, as there were no significant differences seen with exposure to any tested DPP-4 inhibitor in patients with mild, moderate or even severe hepatic impairment, it appears that no dose adjustment is necessary in patients with liver disease, not even for linagliptin despite its specific biliary excretion [5,78,79].

In the absence of head-to-head comparative randomized trials of different DPP-4 inhibitors (for instance, sitagliptin vs vildagliptin), any information can only be found through indirect comparisons. In a meta-analysis of 12 trials with sitagliptin and 11 trials with vildagliptin, the weighted mean differences $v$ s placebo were $-0.79 \%$ (95\% CI: -0.93 to -0.65 ) for sitagliptin and $-0.67 \%$ (95\% CI: -0.83 to -0.52 ) for vildagliptin [8]. In a matchingadjusted indirect comparison of trials in Japanese patients with T2DM, vildagliptin $50 \mathrm{mg}$ twice daily was associated with a slightly but significantly greater $\mathrm{HbA}_{1 \mathrm{c}}$ reduction than sitagliptin $50 \mathrm{mg}$ (difference: $0.28 \%$ ) or $100 \mathrm{mg}$ (difference: $0.35 \%$ ) once daily [80].

However, head-to-head comparisons are scarce, and only one trial has been published as a full report so far. In this 18 -week non-inferiority trial comparing the efficacy of saxagliptin $5 \mathrm{mg}$ once daily and sitagliptin $100 \mathrm{mg}$ once daily in T2DM patients with glycaemia inadequately controlled by metformin, the adjusted mean changes in $\mathrm{HbA}_{1 \mathrm{c}}$ were $-0.52 \%$ and $-0.62 \%$, respectively (Table 2 ). The between-group difference was $0.09 \%$ (95\% CI: 0.01 to $0.20 \%$ ), demonstrating non-inferiority. The safety profile was similar for the two DPP-4 inhibitors, with modest weight loss and almost no increase in the incidence of reported or documented hypoglycaemic episodes [42]. 


\subsection{Gliptins in special populations}

\subsubsection{Patients with renal impairment}

Therapeutic options for patients with T2DM and chronic kidney disease are limited because a reduced glomerular filtration rate (GFR) results in the accumulation of certain drugs and/or their metabolites [81]. The pharmacokinetic characteristics of five DPP-4 inhibitors have been studied in subjects with varying degrees of renal impairment $(\mathrm{RI}):$ mild $=$ creatinine clearance $50-80 \mathrm{~mL} / \mathrm{min}$; moderate $=30-50 \mathrm{~mL} / \mathrm{min}$; and severe $=<30$ $\mathrm{mL} / \mathrm{min}$, including patients with end-stage renal disease (ESRD) [5,82]. According to the results, dose adjustment according to creatinine clearance is recommended for sitagliptin ( $50 \mathrm{mg}$ in cases of moderate RI and $25 \mathrm{mg}$ in cases of severe RI), saxagliptin ( $2.5 \mathrm{mg}$ instead of $5 \mathrm{mg}$ in cases of moderate or severe RI) and vildagliptin ( $50 \mathrm{mg}$ once a day instead of $50 \mathrm{mg}$ twice a day). However, no dose adjustments are recommended for linagliptin.

Several post-hoc analyses of phase-III or specific clinical trials have also evaluated both the efficacy and safety of DPP-4 inhibitors in T2DM patients with various degrees of RI. With dose adjustment in a 54-week trial, sitagliptin was generally well tolerated and provided effective glycaemic control in patients with T2DM and moderate-to-severe RI, including patients with ESRD on dialysis [83]. However, in a study assessing dose adjustments of glucose-lowering agents in T2DM patients with moderate to end-stage RI from a large outpatients electronic medical records database, only $15 \%$ of patients with prescriptions for sitagliptin received dosages of the drug appropriate for their degree of RI. Thus, in clinical practice, sitagliptin was frequently used at inappropriate dosages in patients with RI [84].

Saxagliptin $2.5 \mathrm{mg}$ once daily proved to be a well-tolerated treatment option for patients with inadequately controlled T2DM and various degrees of RI, with incidences of adverse events and hypoglycaemic events similar to those with a placebo [85]. In a 12-week study, the reduction in $\mathrm{HbA}_{1 \mathrm{c}}$ was greater with saxagliptin than with a placebo in subgroups of patients with moderate and severe RI, but not in the subgroup with ESRD on haemodialysis. These observations were recently confirmed in a longer follow-up of 52 weeks [86].

A retrospective analysis demonstrated similar safety and tolerability of vildagliptin as an add-on to metformin in T2DM patients with normal renal function and mild RI [87]. Data pooled from 38 studies in which vildagliptin was given for 12 to 104 weeks in patients with T2DM showed that it was effective and well tolerated in the presence of mild or moderate RI [88]. In a recent 24-week study of 515 T2DM patients with moderate or severe RI, vildagliptin added to ongoing antidiabetic therapy had a safety profile similar to that with a placebo.

Furthermore, compared with a placebo, vildagliptin resulted in a statistically and clinically significant decrease in $\mathrm{HbA}_{1 \mathrm{c}}$ in patients with moderate or severe RI [89].

In a large phase-III 24-week study comparing linagliptin $5 \mathrm{mg}$ once daily with a placebo in patients with T2DM, having mild or moderate RI did not influence trough plasma levels of linagliptin [90]. Also, the efficacy (reduction of $\mathrm{HbA}_{1 \mathrm{c}}$ levels) and safety of linagliptin $5 \mathrm{mg}$ was confirmed in T2DM patients with mild or moderate RI in a pooled analysis of three randomized, placebo-controlled, phase-III clinical trials, as well as in $\mathrm{T} 2 \mathrm{DM}$ patients with severe $\mathrm{RI}\left(\mathrm{GFR}<30 \mathrm{~mL} / \mathrm{min} / 1.73 \mathrm{~m}^{2}\right)$ in a randomized, double-blind, placebo-controlled trial specifically targeting such a population [79].

\subsubsection{Elderly patients}

Oral DPP-4 inhibitors are promising new therapies for older patients because of their consistent efficacy and low risk of hypo-glycaemia. However, data for these new agents are still scarce in this population, which has not been particularly well represented in initial clinical trials, highlighting the need for additional specific studies [5]. However, where available, data from elderly subgroups in individual studies are included in this present review along with pooled analyses by age subgroups in clinical programmes involving DPP-4 inhibitors [91]. For elderly patients with T2DM, reductions in $\mathrm{HbA}_{1 \mathrm{c}}$ after treatment with a DPP-4 inhibitor were not significantly different from those seen in younger patients. This was demonstrated in post-hoc pooled analyses of 24-week trials with vildagliptin $100 \mathrm{mg}$ monother-apy in treatment-naive patients aged $>65$ years $v$ s those $<65$ years [92], and with vildagliptin $100 \mathrm{mg}$ as monotherapy or as add-on therapy to metformin in patients aged $>75$ years vs those $<75$ years [93]. The safety profile of vildagliptin was similar in older and younger patients overall. Use of DPP-4 inhibitors in these studies was associated with a low risk of hypoglycaemia, and the agents were weight-neutral [94].

Similar observations have been reported with saxagliptin $5 \mathrm{mg}$ once-daily as monotherapy or as add-on therapy [95], and with alogliptin [47] in T2DM patients aged $>65$ years.

So far, only one clinical trial has been specifically performed in elderly T2DM patients. In this placebocontrolled, 24-week study, sitagliptin treatment (100 or $50 \mathrm{mg}$, depending on renal function) significantly and rapidly improved glycaemic measures (reductions in $\mathrm{HbA}_{1 \mathrm{c}}$ from $0.5 \%$ to $1.6 \%$, depending on baseline levels), 
and was well tolerated with no adverse episodes of hypoglycaemia in patients aged $>65$ years with T2DM without severe RI [96].

Although, so far, there are no available studies of elderly individuals with linagliptin, a specific trial is currently ongoing. However, because of the unique pharmacokinetic characteristics of the compound (in particular, its non-renal elimination route), it is unlikely that any clinically relevant efficacy/safety differences in older $v s$ younger patients with T2DM will be seen with linagliptin therapy [79].

\section{Pharmacoeconomic evaluation}

Although newer incretin-based therapies offer more options for glycaemic control in T2DM and certain advantages compared with other classical glucose-lowering agents [3,4], the cost of the therapy needs to be taken into account when making global comparisons for clinical use [97]. DPP-4 inhibitors are clearly more expensive than SUs, but less expensive than GLP-1 receptor agonists [98]. This means that demonstrable gains in quality of life and/or longevity with these new agents are necessary to prove their economic value to both patients and healthcare systems [99]. Although there are favourable cost-effectiveness and cost-utility data for DPP-4 inhibitors compared with SUs, only scanty preliminary data are currently available [100]. Thus, more economic analyses are required to establish when it will become more cost-effective to switch from SUs to DPP-4 inhibitors [97].

\section{Conclusion}

Despite the wide structural heterogeneity among gliptins and differences in their pharmacokinetic profiles, the data available so far indicate similar glucose-lowering efficacy with DPP-4 inhibitors as either monotherapy or in combination with other hypoglycaemic drugs, similar weight-neutral effects, and comparable safety and tolerability profiles. A composite endpoint including $\mathrm{HbA}_{1 \mathrm{c}}$ reduction, no hypoglycaemia and no weight gain could be used to combine both efficacy and safety criteria, and so provide an integrated benefit/risk ratio for clinical use. Significantly more patients treated by a DPP-4 inhibitor achieved an $\mathrm{HbA}_{1 \mathrm{c}}$ level $<7 \%$ $(53 \mathrm{mmol} / \mathrm{mol})$ or an $\mathrm{HbA}_{1 \mathrm{c}}$ reduction $>0.5 \%$, with no hypoglycaemia and no increase in body weight compared with a SU, and with no weight gain compared with a TZD. This advantage was confirmed with monotherapy in drug-naive T2DM patients as well as with combination therapy mainly with metformin, and the potential advantages of initiating combined metformin-gliptin therapy have been demonstrated in several trials. DPP-4 inhibitors also showed good efficacy as dual therapy in combination with SU or TZD and as oral triple therapy, and when added to basal insulin treatment in T2DM patients. Thus, combination therapy with a DPP-4 inhibitor offers the potential advantage of achieving glycaemic control with no additional tolerability concerns.

Prospective long-term clinical trials are ongoing to confirm the safety/efficacy of DPP-4 inhibitors added to any type of glucose-lowering therapies as regards cardiovascular outcomes [5]. However, it is noteworthy that most of these studies are placebo-controlled trials, and none will directly compare two incretin-based therapies.

Nevertheless, as these trials plan to recruit more than 50,000 T2DM patients and to follow them for 4-5 years, they should provide further valuable information on the long-term efficacy/safety of this new incretin-based class of pharmacological agents.

\section{Disclosure of interest}

A.J. Scheen has received lecture/advisor fees from AstraZeneca/BMS, Eli Lilly, GlaxoSmithKline, Merck Sharp \& Dohme, Novartis, Novo Nordisk, Sanofi-Aventis, Servier and Takeda.

Funding: no sources of funding were used to assist in the preparation of this manuscript. No conflicts of interest are directly relevant to the content of this manuscript.

\section{References}

[1] Krentz AJ, Patel MB, Bailey CJ. New drugs for type 2 diabetes mellitus: what is their place in therapy? Drugs 2008;68:2131-62.

[2] Monami M, Cremasco F, Lamanna C, Marchionni N, Mannucci E. Predictors of response to dipeptidyl peptidase-4 inhibitors: evidence from randomized clinical trials. Diabetes Metab Res Rev $2011 ; 27: 362-72$.

[3] Phung OJ, Scholle JM, Talwar M, Coleman CI. Effect of noninsulin antidiabetic drugs added to metformin therapy on glycemic control, weight gain, and hypoglycemia in type 2 diabetes. JAMA 2010;303:1410-8.

[4] Bennett WL, Maruthur NM, Singh S, Segal JB, Wilson LM, Chatterjee R, et al. Comparative effectiveness and safety of medications for 
type 2 diabetes: an update including new drugs and 2-drug combinations. Ann Intern Med 2011;154:602-13.

[5] Scheen AJ. A review of gliptins in 2011. Exp Opin Pharmacother 2012;13:81-99.

[6] Neumiller JJ, Wood L, Campbell RK. Dipeptidyl peptidase-4 inhibitors for the treatment of type 2 diabetes mellitus. Pharmacotherapy 2010;30:463-84

[7] Scheen AJ, Radermecker RP. Addition of incretin therapy to metformin in type 2 diabetes. Lancet 2010;375:1410-2.

[8] Fakhoury WK, Lereun C, Wright D. A meta-analysis of placebo-controlled clinical trials assessing the efficacy and safety of incretinbased medications in patients with type 2 diabetes. Pharmacology 2010;86:44-57.

[9] Gautier JF, Sauvanet JP. Efficacy of saxagliptin as an add-on to oral monotherapy in the phase 3 clinical development program: Predictive factors of the treatment response in type 2 diabetes. Ann Endocrinol (Paris) 2011;72:287-95.

[10] Nathan DM, Buse JB, Davidson MB, Ferrannini E, Holman RR, Sherwin R, et al. Medical management of hyperglycaemia in type 2 diabetes mellitus: a consensus algorithm for the initiation and adjustment of therapy: a consensus statement from the American Diabetes Association and the European Association for the Study of Diabetes. Diabetologia 2009;52:17-30.

[11] Rodbard HW, Jellinger PS, Davidson JA, Einhorn D, Garber AJ, Grunberger G, et al. Statement by an American Association of Clinical Endocrinologists/American College of Endocrinology consensus panel on type 2 diabetes mellitus: an algorithm for glycemic control. Endocr Pract 2009;15:540-59.

[12] Schweizer A, Couturier A, Foley JE, Dejager S. Comparison between vildagliptin and metformin to sustain reductions in HbA(lc) over 1 year in drug-naive patients with Type 2 diabetes. Diabet Med 2007;24:955-61.

[13] Goldstein BJ, Feinglos MN, Lunceford JK, Johnson J, Williams-Herman DE. Effect of initial combination therapy with sitagliptin, a dipeptidyl peptidase-4 inhibitor, and metformin on glycémie control in patients with type 2 diabetes. Diabetes Care 2007;30:1979-87.

[14] Williams-Herman D, Johnson J, Teng R, Luo E, Davies MJ, Kaufman KD, et al. Efficacy and safety of initial combination therapy with sitagliptin and metformin in patients with type 2 diabetes: a 54-week study. Curr Med Res Opin 2009;25:569-83.

[15] Williams-Herman D, Johnson J, Teng R, Golm G, Kaufman KD, Goldstein BJ, et al. Efficacy and safety of sitagliptin and metformin as initial combination therapy and as monotherapy over 2 years in patients with type 2 diabetes. Diabetes Obes Metab 2010;12:442-51.

[16] Aschner P, Katzeff HL, Guo H, Sunga S, Williams-Herman D, Kaufman KD, et al. Efficacy and safety of monotherapy of sitagliptin compared with metformin in patients with type 2 diabetes. Diabetes Obes Metab 2010;12:252-61.

[17] Goke B, Hershon K, Kerr D, Calle Pascual A, Schweizer A, Foley J, et al. Efficacy and safety of vildagliptin monotherapy during 2-year treatment of drug-naive patients with type 2 diabetes: comparison with metformin. Horm Metab Res 2008;40:892-5.

[18] Schweizer A, Dejager S, Bosi E. Comparison of vildagliptin and metformin monotherapy in elderly patients with type 2 diabetes: a 24 week, double-blind, randomized trial. Diabetes Obes Metab 2009;11:804-12.

[19] Bosi E, Dotta F, Jia Y, Goodman M. Vildagliptin plus metformin combination therapy provides superior glycaemic control to individual monotherapy in treatment-naive patients with type 2 diabetes mellitus. Diabetes Obes Metab 2009;11:506-15.

[20] Jadzinsky M, Pfutzner A, Paz-Pacheco E, Xu Z, Allen E, Chen R. Saxagliptin given in combination with metformin as initial therapy improves glycaemic control in patients with type 2 diabetes compared with either monotherapy: a randomized controlled trial. Diabetes Obes Metab 2009;11:611-22

[21] Pfutzner A, Paz-Pacheco E, Allen E, Frederich R, Chen R. Initial combination therapy with saxagliptin and metformin provides sustained glycaemic control and is well tolerated for up to 76 weeks. Diabetes Obes Metab 2011 ; 13:567-76.

[22] Rosenstock J, Kim SW, Baron MA, Camisasca RP, Cressier F, Couturier A, et al. Efficacy and tolerability of initial combination therapy with vildagliptin and pioglitazone compared with component monotherapy in patients with type 2 diabetes. Diabetes Obes Metab 2007;9: $175-85$.

[23] Rosenstock J, Inzucchi SE, Seufert J, Heck PR, Wilson CA, Mekki Q. Initial combination therapy with alogliptin and pioglitazone in drug-naive patients with type 2 diabetes. Diabetes Care 2010;33:2406-8.

[24] Rosenstock J, Baron MA, Dejager S, Mills D, Schweizer A. Comparison of vildagliptin and rosiglitazone monotherapy in patients with type 2 diabetes: a 24-week, double-blind, randomized trial. Diabetes Care 2007;30:217-23.

[25] Pan C, Yang W, Barona JP, Wang Y, Niggli M, Mohideen P, et al. Comparison of vildagliptin and acarbose monotherapy in patients with Type 2 diabetes: a 24-week, double-blind, randomized trial. Diabet Med 2008;25:435-41.

[26] Kawamori R, Inagaki N, Araki E, Watada H, Hayashi N, Horie Y, et al. Linagliptin provides superior glycémie control compared to voglibose as monotherapy in Japanese patients with type 2 diabetes. Diabetes 2010;59(Suppl. 1):A172-3, 632-P

[27] Nauck MA, Meininger G, Sheng D, Terranella L, Stein PP. Efficacy and safety of the dipeptidyl peptidase-4 inhibitor, sitagliptin, compared with the sulfonylurea, glipizide, in patients with type 2 diabetes inadequately controlled on metformin alone: a randomized, double-blind, non-inferiority trial. Diabetes Obes Metab 2007;9:194-205.

[28] Seek T, Nauck M, Sheng D, Sunga S, Davies MJ, Stein PP, et al. Safety and efficacy of treatment with sitagliptin or glipizide in patients with type 2 diabetes inadequately controlled on metformin: a 2-year study. Int J Clin Pract 2010;64:562-76.

[29] Arechavaleta R, Seck T, Chen Y, Krobot KJ, O'Neill EA, Duran L, et al. Efficacy and safety of treatment with sitagliptin or glimepiride in patients with type 2 diabetes inadequately controlled on metformin monotherapy: a randomized, double-blind, non-inferiority trial. Diabetes Obes Metab 2011;13:160-8.

[30] Ferrannini E, Fonseca V, Zinman B, Matthews D, Ahren B, Byiers S, et al. Fifty-two-week efficacy and safety of vildagliptin vs. glimepiride in patients with type 2 diabetes mellitus inadequately controlled on metformin monotherapy. Diabetes Obes Metab 2009;11:15766. 
[31] Matthews DR, Dejager S, Ahren B, Fonseca V, Ferrannini E, Couturier A, et al. Vildagliptin add-on to metformin produces similar efficacy and reduced hypoglycaemic risk compared with glimepiride, with no weight gain: results from a 2-year study. Diabetes Obes Metab 2010;12:780-9

[32] Filozof C, Gautier JF. A comparison of efficacy and safety of vildagliptin and gliclazide in combination with metformin in patients with Type 2 diabetes inadequately controlled with metformin alone: a 52-week, randomized study. Diabet Med 2010;27:318-26.

[33] Goke B, Gallwitz B, Eriksson J, Hellqvist A, Gause-Nilsson I. Saxagliptin is non-inferior to glipizide in patients with type 2 diabetes mellitus inadequately controlled on metformin alone: a 52-week randomised controlled trial. Int J Clin Pract 2010;64:1619-31.

[34] Forst T, Uhlig-Laske B, Ring A, Graefe-Mody U, Friedrich C, Herbach K, et al. Linagliptin (BI 1356), a potent and selective DPP-4 inhibitor, is safe and efficacious in combination with metformin in patients with inadequately controlled Type 2 diabetes. Diabet Med 2010;27:1409-19.

[35] Scott R, Loeys T, Davies MJ, Engel SS. Efficacy and safety of sitagliptin when added to ongoing metformin therapy in patients with type 2 diabetes. Diabetes Obes Metab 2008;10:959-69.

[36] Bergenstal RM, Wysham C, Macconell L, Malloy J, Walsh B, Yan P, et al. Efficacy and safety of exenatide once weekly versus sitagliptin or pioglitazone as an adjunct to metformin for treatment of type 2 diabetes (DURATION-2): a randomised trial. Lancet 2010;376:431-9.

[37] Bolli G, Dotta F, Rochotte E, Cohen SE. Efficacy and tolerability of vildagliptin vs. pioglitazone when added to metformin: a 24-week, randomized, double-blind study. Diabetes Obes Metab 2008;10:82-90.

[38] Bolli G, Dotta F, Colin L, Minic B, Goodman M. Comparison of vildagliptin and pioglitazone in patients with type 2 diabetes inadequately controlled with metformin. Diabetes Obes Metab 2009;11:589-95.

[39] Blonde L, Dagogo-Jack S, Banerji MA, Pratley RE, Marcellari A, Braceras R, et al. Comparison of vildagliptin and thiazolidinedione as addon therapy in patients inadequately controlled with metformin: results of the GALIANT trial-a primary care, type 2 diabetes study. Diabetes Obes Metab 2009;11:978-86.

[40] Pratley RE, Nauck M, Bailey T, Montanya E, Cuddihy R, Filetti S, et al. Liraglutide versus sitagliptin for patients with type 2 diabetes who did not have adequate glycaemic control with metformin: a 26-week, randomised, parallel-group, open-label trial. Lancet $2010 ; 375: 1447-56$

[41] Pratley R, NauckM, Bailey T, MontanyaE, Cuddihy R, Filetti S, et al. One year of liraglutide treatment offers sustained and more effective glycaemic control and weight reduction compared with sitagliptin, both in combination with metformin, in patients with type 2 diabetes: a randomised, parallel-group, open-label trial. Int J Clin Pract 2011;65:397-407.

[42] Scheen AJ, Charpentier G, Ostgren CJ, Hellqvist A, Gause-Nilsson I. Efficacy and safety of saxagliptin in combination with metformin compared with sitagliptin in combination with metformin in adult patients with type 2 diabetes mellitus. Diabetes Metab Res Rev 2010;26:540-9.

[43] Chapell R, Gould AL, Alexander CM. Baseline differences in A1 C explain apparent differences in efficacy of sitagliptin, rosiglitazone and pioglitazone. Diabetes Obes Metab 2009;11:1009-16

[44] DeFronzo RA, Stonehouse AH, Han J, Wintle ME. Relationship of baseline $\mathrm{HbA}_{1 \mathrm{c}}$ and efficacy of current glucose-lowering therapies: a meta-analysis of randomized clinical trials. Diabet Med 2010;27:309-17.

[45] Hermansen K, Kipnes M, Luo E, Fanurik D, Khatami H, Stein P. Efficacy and safety of the dipeptidyl peptidase-4 inhibitor, sitagliptin, in patients with type 2 diabetes mellitus inadequately controlled on glimepiride alone or on glimepiride and metformin. Diabetes Obes Metab 2007;9:733^t5.

[46] Garber AJ, Foley JE, Banerji MA, Ebeling P, Gudbjornsdottir S, Camisasca RP, et al. Effects of vildagliptin on glucose control in patients with type 2 diabetes inadequately controlled with a sulphonylurea. Diabetes Obes Metab 2008;10:1047-56.

[47] Pratley RE, Kipnes MS, Fleck PR, Wilson C, Mekki Q. Efficacy and safety of the dipeptidyl peptidase-4 inhibitor alogliptin in patients with type 2 diabetes inadequately controlled by glyburide monotherapy. Diabetes Obes Metab 2009; 11:167-76.

[48] Lewin AJ, Arvay L, Liu D, Patel S. Woerle H-J. Safety and efficacy of linagliptin as add-on therapy to a sulphonylurea in inadequately controlled type 2 diabetes. Diabetologia 2010;53(Suppl. 1). S326, 821

[49] Chacra AR, Tan GH, Apanovitch A, Ravichandran S, List J, Chen R. Saxagliptin added to a submaximal dose of sulphonylurea improves gly-caemic control compared with uptitration of sulphonylurea in patients with type 2 diabetes: a randomised controlled trial. Int J Clin Pract 2009;63:1395-406.

[50] Chacra AR, Tan GH, Ravichandran S, List J, Chen R. Safety and efficacy of saxagliptin in combination with submaximal sulphonylurea versus up-titrated sulphonylurea over 76 weeks. Diabetes Vasc Dis Res 2011;8:150-9.

[51] De Fronzo RA, Banting, Lecture. From the triumvirate to the ominous octet: a new paradigm for the treatment of type 2 diabetes mellitus. Diabetes 2009;58:773-95.

[52] Rosenstock J, Brazg R, Andryuk PJ, Lu K, Stein P. Efficacy and safety of the dipeptidyl peptidase-4 inhibitor sitagliptin added to ongoing piogli-tazone therapy in patients with type 2 diabetes: a 24 -week, multicenter, randomized, double-blind, placebo-controlled, parallel-group study. Clin Ther 2006;28:1556-68.

[53] Garber AJ, Schweizer A, Baron MA, Rochotte E, Dejager S. Vildagliptin in combination with pioglitazone improves glycaemic control in patients with type 2 diabetes failing thiazolidinedione monotherapy: a randomized, placebo-controlled study. Diabetes Obes Metab 2007;9:166-74

[54] Hollander P, Li J, Allen E, Chen R. Saxagliptin added to a thiazolidinedione improves glycemic control in patients with type 2 diabetes and inadequate control on thiazolidinedione alone. J Clin Endocrinol Metab 2009;94:4810-9.

[55] Pratley RE, Reusch JE, Fleck PR, Wilson CA, Mekki Q. Efficacy and safety of the dipeptidyl peptidase-4 inhibitor alogliptin added to 
pioglitazone in patients with type 2 diabetes: a randomized, double-blind, placebo-controlled study. Curr Med Res Opin 2009;25:2361-71.

[56] Kaku K, Itayasu T, Hiroi S, Hirayama M, Seino Y. Efficacy and safety of alogliptin added to pioglitazone in Japanese patients with type 2 diabetes: a randomized, double-blind, placebo-controlled trial with an open-label long-term extension study. Diabetes Obes Metab 2011;13:1028-35.

[57] Hollander PL, Li J, Frederich R, Allen E, Chen R. Safety and efficacy of saxagliptin added to thiazolidinedione over 76 weeks in patients with type 2 diabetes mellitus. Diabetes Vasc Dis Res 2011;8:125-35.

[58] Gomis R, Espadero RM, Jones R, Woerle HJ, Dugi KA. Efficacy and safety of initial combination therapy with linagliptin and pioglitazone in patients with inadequately controlled type 2 diabetes: a randomized, double-blind, placebo-controlled study. Diabetes Obes Metab 2011;13:653-61.

[59] Derosa G, Maffioli P, Salvadeo SA, Ferrari I, Ragonesi PD, Querci F, et al. Effects of sitagliptin or metformin added to pioglitazone monotherapy in poorly controlled type 2 diabetes mellitus patients. Metabolism 2010;59:887-95.

[60] Derosa G, Maffioli P, Ferrari I, Mereu R, Ragonesi PD, Querci F, et al. Effects of one year treatment of vildagliptin added to pioglitazone or glimepiride in poorly controlled type 2 diabetic patients. Horm Metab Res 2010;42:663-9.

[61] Mikhail N. Combination therapy with DPP-4 inhibitors and pioglitazone in type 2 diabetes: theoretical consideration and therapeutic potential. Vase Health Risk Manag 2008;4:1221-7.

[62] Scheen AJ, Tan MH, Betteridge DJ, Birkeland K, Schmitz O, Charbonnel B, et al. Long-term glycaemic control with metforminsulphonylurea-pioglitazone triple therapy in PROactive (PROactive 17). Diabet Med 2009;26:1033-9.

[63] Hsia SH, Navar MD, Duran P, Shaheen M, Davidson MB. Sitagliptin compared to thiazolidinediones as a third-line oral antihyperglycemic agent in type 2 diabetes mellitus. Endocr Pract 2011;17:691-8.

[64] Owens DR, Swallow R, Dugi KA, Woerle HJ. Efficacy and safety of linagliptin in persons with Type 2 diabetes inadequately controlled by a combination of metformin and sulphonylurea: a 24-week randomized study. Diabet Med 2011;28:1352-61.

[65] Bosi E, Ellis GC, Wilson CA, Fleck PR. Alogliptin as a third oral antidi-abetic drug in patients with type 2 diabetes and inadequate glycemic control on metformin and pioglitazone: a 52-week, randomized, double-blind, active-controlled, parallel-group study. Diabetes Obes Metab 2011;13:1088-96.

[66] Fonseca V, Schweizer A, Albrecht D, Baron MA, Chang I, Dejager S. Addition of vildagliptin to insulin improves glycaemic control in type 2 diabetes. Diabetologia 2007;50:1148-55

[67] Vilsboll T, Rosenstock J, Yki-Jarvinen H, Cefalu WT, Chen Y, Luo E, et al. Efficacy and safety of sitagliptin when added to insulin therapy in patients with type 2 diabetes. Diabetes Obes Metab 2010;12: 167-77.

[68] Rosenstock J, Rendell MS, Gross JL, Heck PR, Wilson CA, Mekki Q. Alogliptin added to insulin therapy in patients with type 2 diabetes reduces $\mathrm{HbA}(1 \mathrm{C})$ without causing weight gain or increased hypoglycaemia. Diabetes Obes Metab 2009; 11:1145-52.

[69] Barnett AH, Charbonnel B, Li J, Donovan M, Fleming D. Saxagliptin add-on therapy to insulin with or without metformin for type 2 diabetes mellitus: 52-week safety and efficacy. Diabetologia 201 1;54(Suppl. 1):S 108-9.

[70] Hollander P, Raslova K, Skjoth TV, Rastam J, Liutkus JF. Efficacy and safety of insulin detemir once daily in combination with sitagliptin and metformin: the TRANSITION randomized controlled trial. Diabetes Obes Metab 2011 ; 13:268-75.

[71] Reasner C, Olansky L, Seck TL, Williams-Herman DE, Chen M, Terranella L, et al. The effect of initial therapy with the fixed-dose combination of sitagliptin and metformin compared with metformin monotherapy in patients with type 2 diabetes mellitus. Diabetes Obes Metab 2011;13:644-52.

[72] Yoon KH, Shockey GR, Teng R, Golm GT, Thakkar PR, Meehan AG, et al. Effect of initial combination therapy with sitagliptin, a dipeptidyl peptidase-4 inhibitor, and pioglitazone on glycemic control and measures of beta-cell function in patients with type 2 diabetes. Int J Clin Pract 2011;65:154-64.

[73] Ahren B. Novel combination treatment of type 2 diabetes DPP-4 inhibition + metformin. Vase Health Risk Manag 2008;4:383-94.

[74] Neumiller JJ. Differential chemistry (structure), mechanism of action, and pharmacology of GLP-1 receptor agonists and DPP-4 inhibitors. J AmPharmAssoc (2003) 2009;49(Suppl.1):S16-29.

[75] Gallwitz B. GLP-1 agonists and dipeptidyl-peptidase IV inhibitors. Handb Exp Pharmacol 2011;203:53-74.

[76] DeFronzo RA, Okerson T, Viswanathan P, Guan X, Holcombe JH, Mac-Conell L. Effects of exenatide versus sitagliptin on postprandial glucose, insulin and glucagon secretion, gastric emptying, and caloric intake: a randomized, cross-over study. Curr Med Res Opin 2008;24:2943-52

[77] Wysham C, Bergenstal R, Malloy J, Yan P, Walsh B, Malone J, et al. DURATION-2: efficacy and safety of switching from maximum daily sitagliptin or pioglitazone to once-weekly exenatide. Diabet Med 2011;28:705-14.

[78] Baetta R, Corsini A. Pharmacology of dipeptidyl peptidase-4 inhibitors: similarities and differences. Drugs 2011;71:1441-67.

[79] Scheen AJ. Linagliptin for the treatment of type 2 diabetes (pharmacoki-netic evaluation). Exp Opin Drug Metab Toxicol 2011;7:1561-

[80] Signorovitch JE, Wu EQ, Swallow E, Kantor E, Fan L, Gruenberger JB. Comparative efficacy of vildagliptin and sitagliptin in Japanese patients with type 2 diabetes mellitus: a matching-adjusted indirect comparison of randomized trials. Clin Drug Invest 2011;31:665-74.

[81] Abe M, Okada K, Soma M. Antidiabetic agents in patients with chronic kidney disease and end-stage renal disease on dialysis: metabolism and clinical practice. Curr Drug Metab 2011; 12:57-69.

[82] Scheen AJ. Pharmacokinetics of dipeptidylpeptidase-4 inhibitors. Diabetes Obes Metab 2010;12:648-58. 
[83] Chan JC, Scott R, Arjona Ferreira JC, Sheng D, Gonzalez E, Davies MJ, et al. Safety and efficacy of sitagliptin in patients with type 2 diabetes and chronic renal insufficiency. Diabetes Obes Metab 2008;10:545-55.

[84] Meyers JL, Candrilli SD, Kovacs B. Type 2 diabetes mellitus and renal impairment in a large outpatient electronic medical records database: rates of diagnosis and antihyperglycemic medication dose adjustment. Postgrad Med 2011; 123:133-43.

[85] Nowicki M, Rychlik I, Haller H, Warren ML, Suchower L, Gause-Nilsson I. Saxagliptin improves glycaemic control and is well tolerated in patients with type 2 diabetes mellitus and renal impairment. Diabetes Obes Metab 2011;13:523-32.

[86] Nowicki M, Rychlik I, Haller H, Warren M, Suchower L, Gause-Nilsson I, et al. Long-term treatment with the dipeptidyl peptidase-4 inhibitor saxagliptin in patients with type 2 diabetes mellitus and renal impairment: a randomised controlled 52-week efficacy and safety study. Int J Clin Pract 2011;65:1230-9.

[87] Banerji MA, Purkayastha D, Francis BH. Safety and tolerability of vildagliptin vs. thiazolidinedione as add-on to metformin in type 2 diabetic patients with and without mild renal impairment: a retrospective analysis of the GALIANT study. Diabetes Res Clin Pract 2010;90:182-90

[88] Ligueros-Saylan M, Foley JE, Schweizer A, Couturier A, Kothny W. An assessment of adverse effects of vildagliptin versus comparators on the liver, the pancreas, the immune system, the skin and in patients with impaired renal function from a large pooled database of Phase II and III clinical trials. Diabetes Obes Metab 2010;12:495-509.

[89] Lukashevich V, Schweizer A, Shao Q, Groop PH, Kothny W. Safety and efficacy of vildagliptin versus placebo in patients with type 2 diabetes and moderate or severe renal impairment: A prospective 24-week randomized placebo-controlled trial. Diabetes Obes Metab 2011; $13: 947-54$

[90] Del Prato S, Barnett AH, Huisman H, Neubacher D, Woerle HJ, Dugi KA. Effect of linagliptin monotherapy on glycaemic control and markers of beta-cell function in patients with inadequately controlled type 2 diabetes : a randomized controlled trial. Diabetes Obes Metab 2011;13:258-67.

[91] Bourdel-Marchasson I, Schweizer A, DejagerS. Incretin therapies in the management of elderly patients with type 2 diabetes mellitus Hosp Pract (Minneap) 2011;39:7-21.

[92] Pratley RE, Rosenstock J, Pi-Sunyer FX, Banerji MA, Schweizer A, Couturier A, et al. Management of type 2 diabetes in treatmentnaive elderly patients: benefits and risks of vildagliptin monotherapy. Diabetes Care 2007;30:3017-22.

[93] Schweizer A, Dejager S, Foley JE, Shao Q, Kothny W. Clinical experience with vildagliptin in the management of type 2 diabetes in a patient population $>=75$ years: a pooled analysis from a database of clinical trials. Diabetes Obes Metab 2011;13:55-64.

[94] Schwartz SL. Treatment of elderly patients with type 2 diabetes mellitus: a systematic review of the benefits and risks of dipeptidyl peptidase-4 inhibitors. Am J Geriatr Pharmacother 2010;8:405-18.

[95] Doucet J, Chacra A, Maheux P, Lu J, Harris S, Rosenstock J. Efficacy and safety of saxagliptin in older patients with type 2 diabetes mellitus. Curr Med Res Opin $2011 ; 27: 863-9$

[96] Barzilai N, Guo H, Mahoney EM, Caporossi S, Golm GT, Langdon RB, et al. Efficacy and tolerability of sitagliptin monotherapy in elderly patients with type 2 diabetes: a randomized, double-blind, placebo-controlled trial. Curr Med Res Opin 2011;27:1049-58.

[97] Waugh N, Cummins E, Royle P, Clar C, Marien M, Richter B, et al. Newer agents for blood glucose control in type 2 diabetes : systematic review and economic evaluation. Health Technol Assess 2010;14:1-248.

[98] Scheen AJ. DPP-4 inhibitors are favourable to GLP-1 receptor agonists: yes. Eur J Intern Med 2011 (in press).

[99] Sinha A, Rajan M, Hoerger T, Pogach L. Costs and consequences associated with newer medications for glycemic control in type 2 diabetes. Diabetes Care 2010;33:695-700.

[100] Schwarz B, Gouveia M, Chen J, Nocea G, Jameson K, Cook J, et al. Cost-effectiveness of sitagliptin-based treatment regimens in European patients with type 2 diabetes and haemoglobin Alc above target on metformin monotherapy. Diabetes Obes Metab 2008;10(Suppl. $1): 43-55$ 